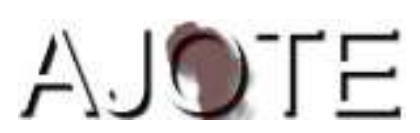

African Journal of Teacher Education

ISSN 1916-7822. A Journal of Spread Corporation

Volume 82019 Pages 139-158

\title{
Adequacy and Utilization of ICT Resources for Teaching Business Subjects in Senior Secondary Schools in Osun State, Nigeria
}

\author{
Lawrence Femi Ademiluyi \\ Department of Business and Entrepreneurship Education \\ Kwara State University Ilorin, Nigeria \\ femiluyi44@gmail.com
}

\begin{abstract}
This study sought to determine the adequacy and utilization of ICT facilities for teaching and learning business subjects in public senior secondary schools in Osun State of Nigeria. Mixed method research design involving the distribution of questionnaires and the conduct of follow-up interviews was used for the study. The population consisted of business educators teaching in public secondary schools. No sample was drawn; the entire population was studied. The results show that ICT facilities are barely available, grossly inadequate and largely unutilized in teaching business subjects in Osun State public secondary schools in spite of the much-heralded introduction of "Opon Imo" computer tablets supposedly made available to all senior secondary school students in the state. The study opined that government and other education stakeholders should provide functional ICT facilities and personnel in public secondary schools.
\end{abstract}

Key Words: Business subjects, Senior Secondary schools, ICT resources, Osun State, Nigeria.

\section{Introduction}

National development is premised on a nation's technological attainment. This has made technology the premier instrument of progress, sustainable development, and self-reliance. Technology is also rapidly emerging as an instrument of national stability and international harmony. It is no accident that the more technologically advanced a nation is, the more stable its politics and social life becomes 
(Ramey, 2012). Furthermore, the advent of information and communication technology is redefining the concept of literacy. In the modern technological environment, literacy is no longer defined by the ability to read and write alone, but also by the ability to use computer and basic information and communication technology facilities. The acquisition, deployment and optimal utilization of Information and Communication Technology (ICT) facilities are therefore major indicators of education service delivery.

The computer has turned out to be, arguably, the most revolutionary implement ever deployed for educational purposes, and is rapidly becoming indispensable to educators and learners alike even in Africa (Ibeneme, 2013). Modern academia uses ICT for virtually everything, from advertising admission to facilitating student application, to applicant admission, development of teaching materials, knowledge impartation, evaluation, and school administration and discipline (Oke, 2012). ICT enables communication, interaction, collaboration, computation, visualization, simulation, and data modeling. It also facilitates instruction, tutoring, mentoring, gathering and filtering of data, consolidation of information and derivation of knowledge. Combinations of all the above are instantiated as multimedia and multimodal applications. It was based on this premise that the government of Osun State of Nigeria made it a policy to provide ICT facilities in public secondary schools in the state (Osun State Government, 2016). However, funding limitations, inadequate ICT infrastructures, and personnel appear to be inhibiting the full realization of the policy objectives.

Nigeria operates the 9-3-4 system of education comprising nine years of basic (six years of primary and three years of junior secondary) education, three years of senior secondary and four years of tertiary education (Federal Ministry of Education, 2014). According to the National Examination Council (2016), business subjects at senior secondary level include Accounting, Commerce, Insurance, Office Practice and Stores Management. NECO also lists the following as entrepreneurship or trade subjects: Marketing, Stenography, Storekeeping, and Salesmanship, among others. All these require significant ICT input if they are to be effectively taught and learnt in contemporary senior secondary schools.

Effective teaching in these fields demands full deployment and application of ICT facilities. Availability and adequacy of ICT facilities depend largely on funding, while utilization may be influenced by teachers' orientation and training, availability of enabling facilities like lighting, and 
public policy. This study seeks to determine the extent to which ICT facilities are being utilized in Osun State's public schools for teaching business subjects.

\section{Literature Review}

Osofisan (2013) describes ICT as the product of the marriage between the computer and the communication industry. It is the product of the merger between computing infrastructure and communication infrastructure. Oke (2012) describes ICT as processing, storage and transfer of information, which can be broken down into information technology hardware and communication. Kwache (2017) posits that it is a general-purpose technology with a major impact on process technologies and product technologies and has social and political implications. Kwache sees ICT as diffusing widely across several industries and sectors of the economy through diverse applications. It is an umbrella term that includes any communication device or application encompassing radio, television cellular phone, computer, network, hardware and software, satellite system, among others, as well as various devices and applications associated with them.

ICT has innumerable educational applications. Oke (2012) opines that two major factors account for the introduction of information communication technology in teaching and learning in schools: students must be familiar with the use of information technology because of its usefulness in all facets of life, and teachers must use information and communication technology in teaching for quality improvement and more effective teaching. Kwache (2017) states that learning resources in education have grown and experienced exponential improvement inline with global technology trends. He stressed further that national development is determined by a nation's technological advancements; this has made technology the cornerstone without which a nation cannot hope to develop.

Osofisan (2013) posits that Information Communication Technology is the handling and processing of information using electronic devices. It simply means the creation, collection, storage, processing, transmission, display and use of information by the people and machine. ICT can also be referred to as the technologies used for accessing, gathering, processing, manipulating and presenting or communicating information. In the opinion of Oke (2012), Information Communication Technology is not only an indivisible part of modern society, but its value in the education sector also cannot be overstated. Oyebanji (2013) asserted that information and communication technologies are vital tools in any educational system with the potentials of being used to meet the learning need of 
individual students, enhance high-quality learning materials, increase self-efficacy and independence of learning among students and improve teachers' professional development. In addition, ICT promotes equality of educational opportunities for learners and teachers. In the same vein, other potentials of contemporary information and communication technology in education include its ability to accelerate and enrich basic skills in reading, writing, and understanding (Kwache, 2017). It motivates and engages students as they are encouraged to be more independent and responsible for their own learning and to relate academic activities to the practices of the contemporary world of work, among others. Brown (2009) is of the view that ICT is very crucial for the achievement of national educational objectives because it expands citizens' access to education at all levels and helps to improve the quality of teaching and learning. ICT-based instructional materials have the capacity to increase learning rates, save the teacher's time and efforts, increase learners' interest and facilitate retention (Onyejemezi, 2009). ICT is well suited for information processing tasks because of its speed, accuracy, and ability to store large data in accessible forms (Atkinson, 2010). At least in the urban parts of West Africa, information technology has provided a mechanism for teachers to keep abreast of increasing demands for current pedagogical information (Asiedu, 2016).

The use of information and communication technology has become indispensable to pedagogy in the different fields of business. Since the dawn of the twenty-first century, businesses have become increasingly dependent on ICTs for virtually all activities. The advent of e-commerce, with its attendant impact on all aspects of business, has meant that, at least in urban centres, little can be achieved in business without constant recourse to information technology. Even in rural parts of Africa, increasing internet access, enhanced by expanding access to cellular telephony, implies that banking and other transactions can now be completed on line with organizations in the neighborhood and others thousands of kilometers away (Punch-Nigeria, 2019).

The social media especially have become veritable instruments of correspondence, advertizing and meetings. Airline and railway bookings, seat and hotel reservations and payments, international trade are now enabled by ICT. International travel papers, shipping documents, visa applications are now processed online. Indeed, especially for students, the wide gulf which existed in Nigeria between rural and urban areas only a couple of years ago is being speedily obliterated as examination bodies insist on conducting online examinations for students irrespective of location. Secondary school students have therefore felt compelled to go outside the regular classroom to 
master aspects of information technology since most school systems have few functional ICT facilities (Ofodu, 2017).

Given this emerging indispensability of ICT to business activities, it is only natural to expect pedagogy in business subjects to be information technology-heavy. However, the application of ICT in business pedagogy depends on the availability of relevant resources and the ICT-dexterity of the teachers. Ofori-Attah (2017) is convinced that both facilities and expertise are in short supply in rural Africa. In spite of this, Social media platforms like Facebook, Twitter, Linkedin, WhatsApp, which are powered mobile devices like smartphones and computer tablets, have emerged as important instruments of education service delivery especially in tertiary institutions and urban centres. Nigerian university teachers give online assignments, feedbacks, deliver lectures on line using social media (Ademiluyi, 2016). At the secondary school level, however, a dearth of human and material resources appears to have stymied the use of Information technology for education service delivery.

A cursory look at the secondary schools in Nigeria reveals that many Business subject teachers in the system still rely heavily on the traditional "chalk and talk" method of teaching rather than embracing the use of ICT. Very few public institutions in Nigeria makes use of contemporary ICT facilities for classroom instructions. Only the private schools have resources for computer-aided instruction; thus, the chalkboard and textbooks continue to dominate teaching and learning activities (Orakpo, 2015; Owuamanan, 2018).

In 2012, the Osun State government introduced Opon Imo tablets for the use of senior secondary school students and teachers. These are off-line, non-interactive computer tablets on which course materials have been loaded. These are available only to final year senior secondary school students. Interactions with the students reveal that the devices contain only revision materials in all subjects rather than comprehensive teaching and learning materials. Apparently, teachers rarely make use of them. It has been argued that students often load extraneous materials on them. Questions have also been raised on their availability and usability especially in rural areas (Fayemi, 2018). It is doubtful, therefore, if the introduction of Opon Imo has improved teaching and learning of business subjects in Osun State of Nigeria.

The question is whether off-line, noninteractive tablets can adequately address the learning needs of students, especially in business subjects. Since business subjects are supposed to prepare students for entry into the business world of the information age, teaching is not likely to be effective 
in the absence of information technology facilities like cable television, computers, overhead projectors, Internet, electronic board, digital multimedia among others. It appears that these facilities are not sufficiently provided for the teaching and learning process in secondary schools of Osun State of Nigeria. This may be detrimental to learning since ICT enables instructors to make learning more immediate and make access to education more equal. Azeez (2018) similarly suggested that a relationship exists between the usage of ICT facilities and academic performance.

Effective use of ICT in teaching and learning of Business subjects depends on the availability of the facilities and teachers' competence in using them (Oyeniran, 2010). Observation and anecdotal inferences suggest that there are, at best, few functional internet facilities in public secondary schools in Osun State. This appears to hinder the extent of teachers' exposure to the use of ICT in teaching. Teachers, as well as students, appear not to be knowledgeable in the use of ICT. Interactions by the researcher with education stakeholders in the state (teachers, headteachers and senior officials of the Ministry of Education) indicate that there has been, in the last ten years, no formal training for teachers on ICT. Indeed, the state's recent public budgets have no provisions for teachers' ICT education (Osun State Government, 2018). It has also been observed that public secondary schools in most parts of Nigeria lack computer-adept business subject teachers while irregular power supply appears to be the norm in the schools. Moreover, it seems the schools could not purchase computers for use because of inadequate funds. Besides, the limited-inclusion of the ICT programmes in teacher training curriculum seems to be another major challenge inhibiting the adoption of ICT in secondary schools. Various studies have identified the multifaceted problems militating against the effective use of ICT in the teaching/learning process in public schools throughout Nigeria. These include: irregular power supply (Ofodu, 2017); inadequate computer literate teachers (Oyebanji, 2013); inadequate funds (Ogunmilade, 2012), reluctance to change (Ademiluyi, 2012) among others. Anecdotal inferences show that Osun State is not exempt from these challenges.

While the government of Osun State of Nigeria has endeavored to introduce basic ICT facilities in senior secondary schools, the adequacy and effectiveness of its efforts remain in question. Government's desire to further deploy ICT facilities in its secondary schools appear to be inhibited by inadequate electricity facilities, funding, and trained personnel. The study sought to determine the extent to which the government has achieved its objectives in spite of identified inhibitions. 


\section{Statement of the Problem}

The government of Osun state, in recognition of the importance of ICT to the impartation and acquisition of knowledge in secondary school business subjects, introduced computer tablets for the use of secondary school students throughout the state. However, the extent to which this policy was followed through has been a subject of controversy. In recent years, secondary school students in Osun State have returned abysmal results in public examinations. For the last four years (2015-2018), Osun state was ranked $29^{\text {th }}$ out of 36 states in West African Examination Council examinations (WAEC, 2018). Students' results in business subjects have reflected this sordid performance. Is this performance level associated with the extent of ICT deployment and utilization for teaching and learning? In the contemporary era, ICT may be the dividing line between effectiveness and ineptitude in teaching and learning. If institutions do not effectively deploy and utilize ICT facilities, the learning process may become sluggish and antiquated, to the detriment of national development efforts. There is, therefore, the need to empirically determine the availability, adequacy, and utilization of ICT resources for teaching and learning of business subjects in senior secondary schools in Osun State, hence the need for this study.

\section{Purpose of the Study}

The purpose of this study is to determine the adequacy and utilization of ICT resources for teaching and learning business subjects in senior secondary schools in Osun State of Nigeria and to determine whether a significant difference exists in the ICT status of rural and urban public schools. The focus of the study was to find answers to the following research questions:

1. How adequate are ICT resources available for teaching business subjects in Osun state secondary schools?

2. To what extent are ICT resources being utilized for teaching business subjects in Osun State secondary schools?

The following hypothesis was also tested at 0.05 level of significance:

There is no significant difference in the mean ratings of business subject teachers in urban and rural areas on the availability and utilization of ICT resources for teaching business subjects in Osun State secondary schools. 


\section{Methodology}

The researcher employed the mixed methods design involving the collection, analysis, and integration of both quantitative and qualitative methods. The quantitative aspect involved the use of descriptive survey instruments. For this purpose, a questionnaire was administered and analyzed. Subsequently, follow up interviews were conducted with of the stakeholders. The interview was designed to seek clarifications and more detailed explanations on items and issues which may not be obvious from the quantitative results obtained from the questionnaire. The population for the study consisted of all business subject teachers who are graduates of business education in public secondary schools in Osun State. The total number is 192. No sample was drawn; the entire population was studied in line with the opinion of Agboola (2007) that it is ideal to study the entire population whenever possible. Twelve of the respondents, selected on the basis of seniority, experience, and location (urban/rural) were subsequently interviewed for clarifications and in-depth insights.

\section{Significance of the Research Area}

The deployment and utilization of ICT facilities are important components of educational service delivery in Nigeria, as in most other developing countries. Business subjects today have huge ICT contents. Subjects like Word Processing, ICT Office Applications and E-Commerce cannot be mastered without adequate access to information technology resources. All other business subjects, to varying degrees, also have significant ICT contents. However, funding inadequacy has pulled education and ICT facilities provision down the pecking order in terms of resource allocation, resulting in poor student performance especially in business subjects.

\section{Method of Data Collection}

A structured questionnaire tagged Adequacy and Utilization of ICT Resources for Business Subjects in Osun State Secondary schools designed by the researcher and duly validated with a Cronbach reliability coefficient of 0.89 was used to gather data for the study. The questionnaire consisted of fifty (50) items designed after an extensive review of literature related to the study. The items were placed on the 4-point rating scale of Highly Adequate $(\mathrm{HE})=4$, Adequate $(\mathrm{A})=3$, Inadequate $(\mathrm{IN})=2$ and Grossly Inadequate $(\mathrm{GI})=1$ for research question 1, while for research question 2, the rating scale is Great Extent $(\mathrm{GE})=4$, Moderate Extent $(\mathrm{ME})=3$, Small Extent $(\mathrm{SE})=2$, and No Extent 
$(\mathrm{NE})=1$. Interviews were subsequently conducted with selected respondents to obtain deeper insight into their responses.

\section{Data Analysis}

A total of 192 copies of the questionnaire was administered, and 181 (94.27\%) were retrieved. The data collected were analyzed using frequency counts, percentage scores for the demographics of the sample, and mean rating and standard deviation to answer the research questions. The decision rule was that scores between 3.50 and 4.00 were regarded as Great Extent or Highly Adequate; scores between 2.50 and 3.49 were regarded as Adequate or Moderate extent; scores between 1.50 and 2.49 were taken as Small Extent or Inadequate while scores of 1.50 and below were rated as No Extent or Grossly inadequate. The null hypothesis designed to determine whether differences exist between respondents in urban areas and those in rural areas was tested at 0.05 alpha level using independent samples t-test.

\section{Sample Demographics}

Of the 181 surveys returned, 124 were from male teachers, 57 were females. 142 of the respondents taught in schools located in urban areas while only 39 taught in schools located in rural areas. 36 of the respondents had second (graduate) degrees, while 141 had first degrees only. Out of the 12 respondents interviewed, seven had over 15 years of teaching experience, three had over 20 years of experience while two had less than eight years of experience.

\section{Results}

Availability of ICT Resources

Table 1: Extent of Availability of ICT Resources for teaching and learning Business Subjects in Osun State public secondary schools.

\begin{tabular}{llll}
\hline S/N Items & Mean & $\begin{array}{l}\text { Standard } \\
\text { Deviation }\end{array}$ & Remarks \\
& &
\end{tabular}

$\begin{array}{llll}\text { 1. Computers } & 1.30 & 0.87 & \text { No Extent } \\ \text { 2. Computer printers } & 1.44 & 0.93 & \text { No Extent } \\ \text { 3. Computer accessories } & 1.44 & 0.93 & \text { No Extent }\end{array}$



4. Internet
1.37
0.85
No Extent
5. Interactive white boards 1.34
0.88
No Extent
6. Computer projectors
1.40
1.06
No Extent
7. Television sets
1.33
0.91
No Extent
8. Computer tablets
2.59
0.97
Moderate Extent
9. Computer teachers
2.19
1.17
Small Extent
10. Teaching software
1.33
1.01
No Extent
11. Computer technicians
2.11
1.13
Small Extent
12. Smart phones
2.41
0.96
Small Extent

Of the twelve items listed, only computer tablets (mean:2.59) was available to a moderate extent; three were available to a small extent. These are computer teachers (Mean: 2.19) and computer technicians (Mean: 2.11) and smartphones (2.41). All others were rated as available to no extent, indicating that these facilities were virtually not available for the teaching and learning of business subjects in public secondary schools in Osun State. The standard deviation ranged from 0.87 to 1.17 which indicated that the scores are not too dispersed from the mean, indicating a broad consensus of opinions.

Adequacy of ICT Resources

Table 2: Adequacy of ICT Resources for Teaching and Learning Business Subjects in Secondary Schools in Osun State

$\begin{array}{llll}\text { S/N Items } & \text { Mean } & \begin{array}{l}\text { Standard } \\ \text { Deviation }\end{array} & \text { Remarks } \\ \end{array}$

1. Computers

1.37

2. Computer printers

1.31

1.40

1.37

4. Internet

5. Interactive white boards

1.31

1.33
0.76

0.84

0.91

0.85

0.78

0.73
Grossly Inadequate

Grossly inadequate

Grossly inadequate

Grossly inadequate

Grossly inadequate

Grossly inadequate 
7. Television sets

8. Computer tablets

9. Computer teachers

10. Teaching software

11. Computer technicians

12. Smart phones

13. Training Opportunities for teachers

14. Training opportunities for technicians

15. Teacher motivation
1.33

2.45

2.19

1.33

2.11

1.41

1.30

1.30

1.21
$0 . .73$

1.08

1.17

1.01

1.13

0.96

0.65

0.65

0.43
Grossly inadequate

Inadequate

Grossly inadequate

Grossly inadequate

Grossly inadequate

Grossly inadequate

Grossly inadequate

Grossly inadequate

Grossly inadequate

All the items without except computer tablets (Mean: 2.45) were rated as grossly inadequate. The items with the least score is teacher motivation (Mean: 1.21), training opportunities for teachers (Mean: 1.30) and technicians (Mean: 1.30). The low standard deviation figures ranging from 0.43 to 1.13 indicate a broad consensus on the abysmal rating on the adequacy of ICT resources for the teaching and learning of business subjects in public secondary schools in Osun State. A juxtaposition of the findings in Tables 1 and 2 shows that while certain items are indeed available, albeit to moderate or small extent, all items are uniformly inadequate for the use of students. These include computer tablets, teachers and technicians. These facilities and personnel indeed exist in the school systems but are insufficient in quality and quantum for teaching and learning business subjects.

Utilization of ICT Resources

Table 3: Extent of Utilization of ICT Resources for teaching and learning Business Subjects in Osun State public secondary schools.

\begin{tabular}{llll}
\hline S/N Items & Mean & $\begin{array}{l}\text { Standard } \\
\text { Deviation }\end{array}$ & Remarks \\
\hline 1. Computers & 1.33 & 0.86 & No Extent \\
2. Computer printers & 1.40 & 0.90 & No Extent
\end{tabular}




$\begin{array}{llll}\text { 3. Computer accessories } & 1.40 & 0.90 & \text { No Extent } \\ \text { 4. Internet } & 1.38 & 0.88 & \text { No Extent } \\ \text { 5. Interactive white boards } & 1.34 & 0.88 & \text { No Extent } \\ \text { 6. Computer projectors } & 1.47 & 1.01 & \text { No Extent } \\ \text { 7. Television sets } & 1.31 & 0.96 & \text { No Extent } \\ \text { 8. Computer tablets } & 2.34 & 0.97 & \text { Small Extent } \\ \text { 9. Computer teachers } & 1.37 & 1.17 & \text { No Extent } \\ \text { 10. Teaching software } & 1.35 & 0.97 & \text { No Extent } \\ \text { 11. Computer technicians } & 1.41 & 1.13 & \text { No Extentt } \\ \text { 12. Smart phones } & 1.41 & 0.96 & \text { No Extent }\end{array}$

The results in table 1 shows that out of the twelve items, 11 were rated as being utilized to no extent while only one, computer tablets (Mean: 2.34) has been utilized to a small extent. No item was influenced to a great extent or moderate extent.

\section{t-test Analysis of Difference in the Mean Ratings of Business Subject Teachers on Adequacy and Utilization of ICT Facilities}

$\begin{array}{lllllllll}\text { Group } & \text { N } & \text { Mean } & \text { SD } & \text { t-cal } & \text { Df } & \begin{array}{l}\text { P-value } \\ \text { (Fixed) }\end{array} & \begin{array}{l}\text { P-value } \\ \text { (Observed) }\end{array} & \text { Decision } \\ \text { Urban } & 142 & 1.49 & 0.97 & & & & & \\ & & & & 0.351 & 179 & 0.05 & 0.143 & \text { Accept (NS) } \\ \text { Rural } & 39 & 1.43 & 0.94 & & & & & \end{array}$

The result of the test of the null hypothesis at 0.05 alpha level shows that while respondents from schools located in urban areas were 142 in number, those from rural areas numbered 39 . The mean scores for both groups were 1.49 and 1.43 respectively while the standard deviations were 0.97 and 0.94. The computed t-value is 0.351 while the observed P-value is 0.143 . Since the observed $\mathrm{P}$ value $(0.143)$ is greater than the fixed level of significance $(0.05)$, the null hypothesis of no 
significant difference was accepted. This implies that the study recorded no significant difference in the ratings of respondents in urban and rural areas on adequacy and utilization of ICT facilities for teaching business subjects in Osun State secondary schools.

\section{Insight from Interviews}

Interviews conducted with selected respondents shed some light on the responses on the adequacy and utilization of ICT resources in Osun State. The respondents uniformly indicated that because public schools were being poorly funded, ICT facilities for teaching business subjects had not been adequately provided. According to one respondent, too many forces militate against the utilization of ICT facilities in the state. These include poor funding, weak internet facilities, poor maintenance culture, and poor staff motivation, among others. A teacher further explained that in a few schools, the Parents and Teachers Association might provide one or two desktop computers for the use of the entire school, leaving the school authorities to work out the means of providing access to the devices by hundreds of students. Another teacher pointed out that public school teachers were being owed several months of salaries; hence the provision of ICT facilities was not a priority to either the government or the staffers. Similarly, no one regarded training in the usage of ICT for business education pedagogy as a priority.

According to another respondent, the divide in ICT usage throughout Nigeria is not so much between rural and urban schools, but between private and public schools. "While high brow private schools and the few elite public schools are well stocked with facilities of all types, public schools suffer from severe infrastructural neglect." Another respondent explained: "It is a class thing. The elites never send their children to public schools, except the Federal Government Colleges which has space for less than two percent of the student population. They send their children to private schools where indeed state of the art facilities are often available in reasonable numbers."

In respect of the computer tablet designed for students, all respondents interviewed agreed that it was a progressive initiative but felt that the contents, distribution, and management should be improved. "The tablets should not be regarded as an alternative to conventional computer and other ICT facilities. The tablets should be interactive and must be amenable to internet access." 


\section{Discussion of Findings}

The study examined adequacy and utilization of ICT resources for the teaching and learning of business subjects in senior secondary schools in Osun State of Nigeria. From the findings on Table 1 , it is clear that only computer tablets were available to a moderate extent; smartphones, computer teachers and technicians were available to a small extent while all the others were available to no extent. This confirms the observation that Opon Imon, the computer tablet had been made largely available especially to final year students in secondary schools. All other ICT facilities needed for successful teaching and learning of business subjects in senior secondary schools were virtually not available. This shows that the submission of Okebukola (2007) that Nigerian secondary schools do not have adequate ICT facilities for teaching and learning has not perceptibly improved. Apparently, the injection of computer tablets has not effectively addressed this deficit in Osun State.

The findings in Table 2 on the adequacy of ICT facilities for teaching and learning business subjects in senior secondary schools shows that only one item, computer tablet was rated as inadequate. All others were rated as grossly inadequate. Given the dismal rating on availability as reported in the first table, only a similarly dismal rating could have been expected in respect of adequacy. Ademiluyi (2012) indicates that for students to have the best benefits from ICT, the facilities must not only be available but also adequate. Where the facilities are unavailable, they cannot be adequate.

The findings on the second research question which addressed the question of utilization of ICT resources for teaching and learning business subjects shows that again, only the computer tablets were being utilized to a small extent. All others were not being utilized at all simply because they were not available. Babajide (2013) posits that in most Nigerian schools, ICT facilities are not being utilized because they are not available. Even the computer tablets, which are only marginally available, are being utilized to a small extent, perhaps because of the questionable quality of its content and the pupils' adaptation to it.

The result of the test of hypothesis shows no significant difference in respondents' mean ratings on adequacy and utilization of ICT resources for teaching business subjects in public secondary schools in Osun State. This finding is attributable to the fact that urban and rural schools are uniformly funded by the government, making no distinction in the provision of ICT resources between urban and rural schools. Private schools are apparently a different kettle of fish. 
Oyebanji (2013) is of the opinion that private secondary schools, especially those owned by religious bodies and multinational organizations are better equipped, better staffed and better managed than public schools. He is also of the opinion that while urban and rural public secondary schools may differ in provision of physical infrastructural facilities, they do not significantly differ in provision of teaching resources, except in those schools - urban or rural - where the Parent/Teachers Association has taken it upon itself to fund the provision of much needed facilities.

The fundamental finding of the study is that ICT facilities are virtually not available, and where they are, they are grossly inadequate and are therefore not being utilized for teaching and learning of business subjects in Osun State owned secondary schools. While the Opon Imon, was introduced with fanfare as the cure-all tablet for all academic ailments in Osun state secondary schools, the result of this study appears to validate the reports of students' woeful performances in public examinations, not only in business subjects, but in all subjects. This shows that the off-line, non-interactive computer tablets have not satisfactorily complemented or replaced the computer, the internet, and other ICT facilities as an instrument for teaching and learning of business subjects.

The introduction of the tablets is arguably a step in the right direction and should not be discouraged; however, there is much more to teaching and learning in the Information Age than noninteractive tablets. If the society is to catch up with those optimizing the use of ICT facilities for business teaching and learning, the provision of ICT facilities and personnel needs to be prioritized and better funded.

\section{Conclusion}

The finding of this study has shown that Osun state public secondary schools are lagging behind in the level of application of ICT facilities in the teaching-learning process in Osun State. There is a stark dearth of ICT facilities in public secondary schools while the capacity for using facilities by both teachers and students is also very low. Despite the proven benefits in the use of ICT in schools, many factors impede the successful application of ICT in public secondary schools. In order to fit into the new scientific order, it is necessary for the government and relevant education support agencies in Osun State of Nigeria to provide ICT facilities in schools and encourage its use through reorientation of students and training of teachers. 


\section{Recommendations}

The following recommendations are proffered to redress the ICT situation in public secondary schools:

1. The government should provide computers and computer accessories for the teaching and learning of business subjects in secondary schools. The current situation in which most schools have no computer for teaching and learning of business subjects needs to be expeditiously addressed

2. Students and teachers must be re-orientated away from the chalk and board culture to embrace ICT teaching and learning. This will make the process of knowledge acquisition and impartation easier for all concerned,

3. Training and retraining must be provided for teachers who are to teach business subject using ICT facilities. Since no one can give what he does not have, no one can impart the knowledge he does not possess.

4. Basic facilities should be provided in secondary schools. The government should find means of improving electricity supply to secondary schools. Also, cheap internet access should be provided for students and teachers alike

5. The computer tablets currently provided should be made available to every senior secondary student; not only those in the final year. The tablet should have online accessibility, be made interactive, and the content should be more in-depth and thorough.

6. There should also be continuous and periodic training of Business Studies teachers on computer and Computers skills acquisition. This will help provide them with practical and functional knowledge of the computer, the internet and associated areas of ICT with the hope of integrating it with instructional methods of teaching and learning.

\section{References}

Ademiluyi, L. F. (2012). Wedlock of the gods: Using vocational education and ICT for the promotion of entrepreneurship and accelerated national development. Gateway Journal of Business Education 3(1), 77-82.

Agboola, J. M. (2011). Research techniques. Ibadan: Newdeal Publications Nig Ltd. 
Ajayi, I. A., Ekundayo, H.T. (2017). Funding initiatives in university education in Nigeria.

Babalola, J. B., Akpa, G. O., Ayeni, A.O., Adedeji SO (eds) Access, equity and quality in higher education. Ibadan: Awemark Printers.

Ajayi, I. A. (2008). Towards effective use of information and communication technology for teaching in Nigerian colleges of education. Asian J. Inf. Technol. 7(5): 210 - 214.

Akubuilo, D.U. (2007). Effective utilization of information and communications technology (ICT) in science instruction at the Tertiary Level: some inhibiting factors. In Babalola J.B,Akpa, G.O, Ayeni, A,O, Adedej, O. (eds) Access equity and quality in higher education. National Association for Educational Administration and Planning (NAEAP) Publications, Ibadan: Awemark Printer.

Aribisala, J.O. (2016). Role of information and communication technology in globalization. In Agagu AA (ed). Information and Community Technology and computer applications. Abuja: Panof Press.

Atkinson S. C. (2010). Fundamentals of Information Technology. Dublin: Seagull Books

Azeez B. Z. (2018). ICT skills acquisition and utilization by confidential secretaries in Lagos Metropolis. Lagos Journal of Information Technology, 3(1), 37-43.

Babajide, V.F.T., Bolaji, O.A. (2013). Perception of lecturers and service teachers towards the use of communication media in teaching pure and applied science related discipline. $44^{\text {th }}$ Annual STAN Conference proceedings pp. 33 - 36.

Bandele, S.O. (2006). Development of modern ICT and internet system. In Agagu AA (ed). Information and communication technology and computer Applications. Abuja: Panof Press.

Brown A.J. (2009). Fundamental Concepts of information technology. Sydney:

Bryers, A. P. (2014). Psychological evaluation by means of an on-line computer. Behaviour Research Method and Instruction, 13, 585 - 587.

Dabesaki, M (2015). e-Education in Nigeria: challenge and projects. Paper presented at the $8^{\text {th }}$ UNICT TASK force meeting Dubin Ireland. 
Fayemi, F. F. (2018). ICT skills of office managers in Lagos metropolis. Unpublished M.Sc Thesis of the Department of Business Education, Kwara State University Malete

Ibeneme, O. T. (2013). Interface between vocational education and information and communication technology. Journal of Information and Communication Technology, 5(1), 123-142.

Jimoh, A. T. (2007). Students' attitude toward ICT in Nigeria tertiary institutions. Educ. Focus $5(1), 73-79$.

Kwache, P.Z. (2017). The imperatives of information and communication technology for teachers in Nigeria higher education. MERLOT Journal of Online learning and teaching. 3(4): 359 - 399.

Ofodu, GO (2017). Nigeria Literary educators and their technological needs in a digital age.

Education Focus 5(1), 22 - 30.

Ofori-Attah, K., J. (2017). Challenges of Information and Communication Technology in modern organizations. Unpublished paper presented at Ghana Institute of Management and Public Administration, April $21^{\text {st }}$.

Ogunmilade, CA (2012). Television for Instruction. Television Quarterly 7: 7-11.

Okebukola, P (2007). Old, new and current technology in education. UNESCO Africa. 14(15): 7-18.

Oke, J. S. (2013). The Challenge of a new reality: Information and communication technology and the new frontiers of knowledge. Journal of Information and Communication Technology, 5(1), 12-22.

Olorunsola, E.O. (2007). Information Communication Technology. A tool for effective management in Nigerian universities. Educ to implementation of information and communication technology in science. Focus 1(1): 80 - 87. 
Onyejemezi C.C. (2009). ICT skills needed by Higher National Diploma Office Technology and Management students for effective office administration. Unpublished M.Ed dissertation, Department of Business Education, Nnamdi Azikiwe University, Awka.

Osofisan, A. O. (2013). Information and communication technology in the new education.

Journal of Information and Communication Technology 5(1), 2-11.

Osun State Government (2018). Budget of the State of Osun. Osogbo: Osun State Government Press.

Oyebanji P.K. (2013). Teacher training: Key technology and mathematics teaching. In M. A. G.

Akale (ed) Proceeding of the $44^{\text {th }}$ Annual Conference of Science Teachers' Association of Nigeria pp. 265-267.

Oyeniran, S. G. (2010). Opportunities and challenges of Information and communication technology. Journal of Business Education, 5(1), 33-42.

Punch Nigeria (2019). ICT Education and the 2019 budget proposal. Accessed on htpps://www.punchonline.com. Accessed on November 3, 2018.

Ramey S. T. (2012). Issues and challenges in ICT pedagogy. Asian Journal of Information and Communication Technology, 7(2), 55-59.

Russel, A. S. (2009). E-Learning strategies in New Zealand universities. New Zealand Journal of information technology, 23 (4),3043-3044.

Nwite O (2007). Utilization of information and communication technology in schools: problem and suggestions. In Babalola, J.B., Akpa, G.O., Ayeni, A.O., Adedeji, S.O. (eds) Access, equity and quality in higher education. National Association for Educational Administration and Planning (NAEAP) Publications. Ibadan: Awemark Printers.

Selwyn N (1997). Teaching information technology to the 'computer shy'. A theoretical perspective on a practical problem. J. Vocat. edu. Train. 49(3): 395-408.

West African Examination Council (2018). 2018 may/June examination results. https://www.waeconline.org.ng. Accessed on November 27, 2018. 
Yusuf M.O. (2005). Information and communication technology: Analysing the Nigerian

National policy for information technology. International. Education Journal. 6(3): 316-332. 